\title{
COMPARISON OF CHILEAN NATURAL PHOSPHATIC MINERALS
}

\author{
Carlos Rojas W. \\ Instituto de Investigaciones Agropecuarias, INIA, La Platina \\ Santiago,Chile. \\ Correo electrónico: crojas@inia.cl.
}

\section{Comparación de minerales fosfáticos naturales chilenos}

Keywords: Phosphatic ores, rock reactivity, Andisols, agronomical use

\begin{abstract}
The begining of phosphatic deposits study was dated around 1963 through the survey developed at Bahia Tongoy, and later on at Pachingo in 1989. In this article, a synthesis of the main geological, physico-chemical, and agronomic features of these materials is presented, remarking some of these properties, and agronomical applications obtained after the accomplished research. Location of deposits is described, as well as their origin and phosphorus enrichment. Some solubility results of Chilean rocks is compared with other reactive rocks of USA, and Latinoamerica. Results of classical rock composition, is compared with some Chilean rocks, located at the north region of Chilean territory. Actualized figures of phosphate rock production at Chilean market, is also presented in this paper. Major conclusions obtained through field research in Andisols, show that these national phosphate rocks have an important fertilizer potential. The most remarkable phosphorus content and high reactivity was Bahia Inglesa rock; Mejillones showed similar efficiency to Tampa rock when it was employed as concentrated material. Vegetable species of major efficiency in the uptake of available P from these sources, were those of longer vegetative period, such as grass, and high $\mathrm{P}$ uptake as lupins or rape seeds, and also flooded rice.
\end{abstract}

Palabras Claves : minerales fosfáticos, reactividad de las rocas, Andosoles, uso agronómico. 


\section{RESUMEN}

El comienzo de los estudios de los depósitos fue alrededor del año 1963 a través del estudio efectuado en la Bahía de Tongoy y posteriormente, en Pachingo en el año 1989. En este artículo, se presenta una síntesis de las principales características geológicas, fisicoquímicas y agronómicas de estos recursos, luego de completarse éstas investigaciones. Se describe la localización de los depósitos, así como su origen y potencia. Algunos resultados de solubilidad de las rocas chilenas se comparan con otras rocas reactivas de Estados Unidos y Latinoamérica. Resultados de la clásica composición de las rocas, se compara con las rocas chilenas, localizadas en la región norte del territorio nacional. Se presentan también cifras actualizadas de producción de rocas fosfóricas en el mercado chileno. Las principales conclusiones obtenidas a través de las investigaciones de campo en suelos Andosoles, demuestran que las rocas fosfóricas nacionales consideradas, tienen un potencial fertilizante de importancia. La más notoria por su contenido de fósforo y alta reactividad fue la roca de Bahía Inglesa, la de Mejillones mostró una eficiencia similar a la roca de Tampa cuando se empleó como material concentrado. Especies vegetales de mayor eficiencia en la absorción de $\mathrm{P}$ disponible a partir de estas fuentes, fueron aquellas de más largo período vegetativo, tales como los pastos, y aquellas de alta absorción de $\mathrm{P}$ tales como los lupinos o raps y también el arroz inundado.

\section{INTRODUCTION}

The National Service of Geology and Mining in Chile (SERNAGEOMIN), began the exploration of phosphatic deposits in Chile around 1963 beginning by Bahia Tongoy and in 1976 with the Project «Fosforitas de Mejillones», detecting a first deposit of importance in Chile. Later, between 1982 and 1985, Corporación de Fomento de la Producción and the Comisión Chilena de Energía Nuclear, studied the area of Bahia Inglesa, detecting the second deposit of importance. Both institutions from 1980 explored Bahia Salado (Besoaín et.al., 1989). Later, the three companies studied the Area accurately in Puerto AldeaTongoy-Pachingo indicating itself that this area displays the best options to detect new resources of natural phosphate minerals. The phosphoric matrix of rocks of Mejillones and Bahia Inglesa is the fluorine-carbonate apatite. They are "francolitas" of marine sedimentary origin with high degree of isomorphic phosphate substitution by carbonate, therefore with good fertilizing value. The rocks of La Serena, however, are classified as clorhidroxiapatitas of metamorphic igneous origin with low solubility. The rocks of Mejillones and Bahia Inglesa are of highly reactive if they are used in volcanic soils at acid $\mathrm{pH}(<6)$, and containing high levels of organic matter.

In this work, a synthesis of the main geologic characteristics are presented. Physico-chemical and agronomical performance of Chilean phosphoric rocks, by means of recent results obtained are showed too.

\section{Location of deposits}

The Chilean deposits are considered of moderate quality for their industrial management. They are located to the North from Mejillones (III Region to $23^{\circ}, 06$ 'S and $\left.70^{\circ} 27^{\prime} \mathrm{W}\right)$, Bahia Inglesa, Bahia Salado, Bahia Tongoy, Puerto Aldea and Pachingo 
to the south (Figure 1). One is fosforitas of marine sedimentary origin with some associated apatite deposits to igneous and metamorphic rocks of plutonic contact and granite. They are located in a strip piece of land extended between the III and IV Regions. Metric tons with contents of 6$17 \%$ of $\mathrm{P} 205$ are considered the total reserves of "fosforita" in 3,7 x108 metric tons.
Reserves of greater law, 12-30\% of P205, which do not surpass $3.2 \times 106$ metric tons are also included. Recently, Food and Agriculture Organization Of The United Nations (FAO, 2004), has made a compilation of the world-wide phosphoric rock information and has mentioned some of these national resources.

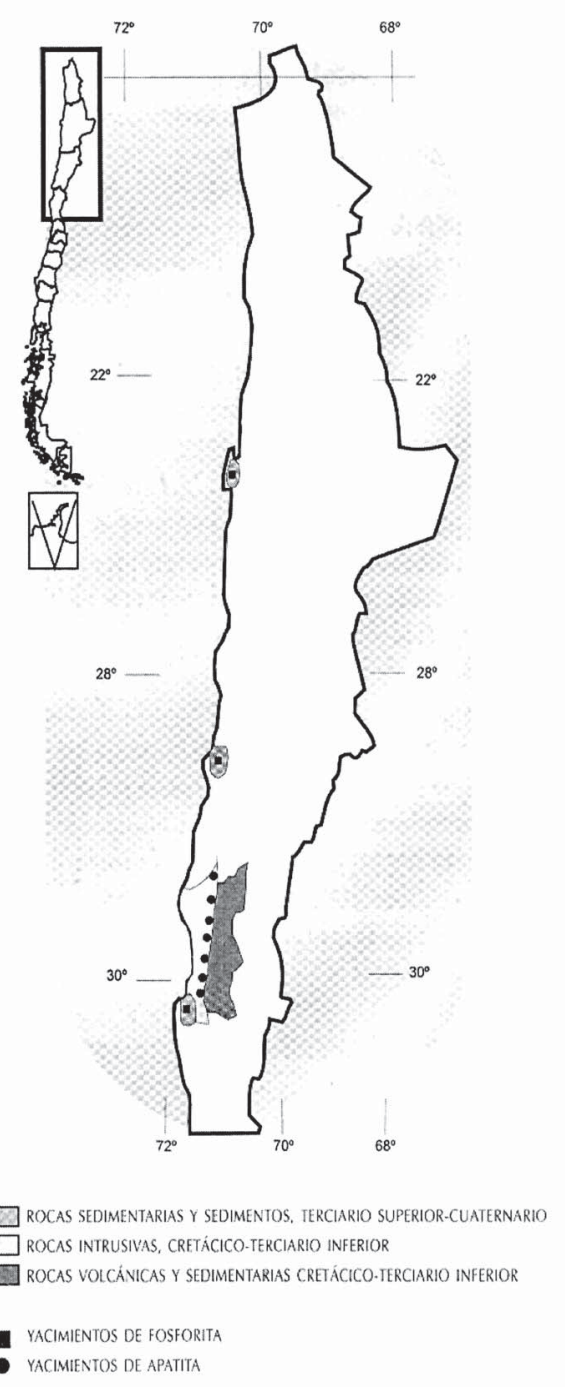

Figure 1: Distribution of the main deposits of Chilean phosphoric rocks (Guarachi., 1989) Figura 1: Distribución de los principales yacimientos de rocas fosfóricas chilenas.

(Guarachi., 1989) 
Table 1: Main phosphoric rock deposits in Chile and its general characteristics (Adapted of Valdebenito and Gutierrez., 1979; Osses, 1986).

Cuadro 1: Principales depósitos de rocas de Chile y sus de Chile y sus carcaterísticas generales (Adaptado de Valdebenito y Gutierrez. 1979; Osses., 1986).

\begin{tabular}{|l|l|l|l|l|}
\hline $\begin{array}{l}\text { Phosphatic } \\
\text { minerals }\end{array}$ & $\begin{array}{l}\text { Associated } \\
\text { Rocks }\end{array}$ & $\begin{array}{l}\text { Location of } \\
\text { Deposits }\end{array}$ & $\begin{array}{l}\text { Law Average } \\
\mathrm{P}_{2} \mathrm{O}_{5} \%\end{array}$ & Metric tons \\
\hline APATITE & $\begin{array}{l}\text { Igneas and } \\
\text { metamorphic } \\
\text { granitical } \\
\text { contacts }+ \\
\text { plutones. }\end{array}$ & $\begin{array}{l}\text { Western sector } \\
\text { of III and IV } \\
\text { Regions. } \\
\text { Pampa Soledad } \\
\text { (Chañaral) }\end{array}$ & $12-30$ & 4 millions \\
& $\begin{array}{l}\text { marine } \\
\text { sedimentarias } \\
\text { Rocks, fluorine } \\
\text { carbonates } \\
\text { apatites or } \\
\text { francolitas }\end{array}$ & $\begin{array}{l}\text { Rejillones. II } \\
\text { Region } \\
\text { Bahia Inglesa } \\
\text { Bahia Salado } \\
\text { III Region } \\
\text { Tongoy- } \\
\text { Guanaqueros } \\
\text { IV R. }\end{array}$ & $\begin{array}{l}7-17 \\
\text { Arauco, VIII } \\
\text { Region }\end{array}$ & $\begin{array}{l}\text { Non } \\
\text { estimated }\end{array}$ \\
\hline
\end{tabular}

The main Chilean phosphoric rock deposits, location and origin, are observed in Table 1.

These information, consider the deposits of the continental land and no those of marine resources considering the Economic Exclusive Zone $\left(4.264 .560 \mathrm{~km}^{2}\right)$, whose presence seem to be of great magnitude, but its potential depends on the training of human resources in the future exploration and economic feasibility of industrial operation of these resources (Vergara $\mathrm{H}$.
Professor, Instituto de Oceanología, University of Valparaiso, Personal communication).

\section{Chemical characteristics of phosphate minerals}

Actually, we know with certain precision the principles of the physico-chemistry involved in the fertilizing efficiency of rocks, therefore it is possible to deduce after an 
efficient characterization its fertilizing potential. This effect is also related to the interaction of rocks with soils properties such as: soil $\mathrm{pH}$, organic matter content, soil mineralogical composition, exchangeable calcium content, and also phosphorus adsorption capacity of the soil.

All this interactions are also related with plant roots growth behaviour (Rojas and Besoain, 1991)

\section{Solubility of rocks}

The solubility of rocks, is one the first approach to predict the chemical reactivity, in this case the rocks are grinded out and sifted through 100 mesh. They are treated with diverse extractants such as $2 \mathrm{M}$ of citric acid and $2 \%$ formic acid.

Some results of solubility in Chilean rocks are shown in Table 2, In comparison with some rocks of Peru, Colombia and from North Carolina, the last rocks is described with high reactivity. It is observed that in Latin America, the rock of Peru (Bayovar) perform as a high reactivity, as it is proved in any of the used extractant solubility.

The solubility to neutral ammonium citrate has been obtained after one second extraction, this treatment release the free carbonates which can mask the results of the first extraction and, in this way we are able to obtain an approach of its relative agronomic potential (Leon, 1999).

Table 2: Chemical reactivity of some phosphoric rocks of Latin America including Chilean phosphoric rocks.

Cuadro 2: Reactividad química de algunas rocas fosfóricas de Latinoamérica incluyendo rocas fosfóricas chilenas.

\begin{tabular}{|c|c|c|c|c|c|}
\hline \multicolumn{6}{|c|}{ Solubility of Phosphoric rock } \\
\hline $\begin{array}{c}\text { Phosphoric } \\
\text { rock }\end{array}$ & $\begin{array}{c}\text { Neutral } \\
\text { ammonium } \\
\text { citrate }^{1}\end{array}$ & $\begin{array}{c}2 \% \text { Citric } \\
\text { acid }\end{array}$ & $\begin{array}{c}2 \% \text { formic } \\
\text { acid }\end{array}$ & $\begin{array}{c}\text { Ammonium } \\
\text { Citrate }\end{array}$ & $\begin{array}{c}\text { Absolute } \\
\text { soubility in } \\
\text { Citrate }\end{array}$ \\
\hline \multicolumn{6}{|l|}{ Chile } \\
\hline La Serena & 0.14 & 2.90 & 3.40 & --- & --- \\
\hline Mejillones & 0.26 & 2.10 & 1.70 & -- & --- \\
\hline Bahía & 2.35 & 3.90 & 4.11 & 4.54 & --- \\
\hline Inglesa & & & & & \\
\hline \multicolumn{6}{|l|}{ Colombia } \\
\hline Huila & 1.50 & 2.30 & 2.70 & 10.50 & 12.20 \\
\hline Pesca & 0.80 & 3.00 & 2.30 & 8.50 & 9.70 \\
\hline \multicolumn{6}{|l|}{ Perú } \\
\hline Bayovar & 2.40 & 6.60 & 9.50 & 24.10 & 14.90 \\
\hline \multicolumn{6}{|l|}{ USA } \\
\hline North Caroline & 3.10 & 6.90 & 11.20 & 19.80 & --- \\
\hline
\end{tabular}

1 Second Extraction. 


\section{Mineral composition of rocks}

The apatite is the main component of the phosphoric rocks (Lehr, 1967). According to Chien, (1977), the solubility of rocks increases when the phosphate substitution by carbonates in the structure of the apatite is also increased. Thus, the degree of isomorphic substitution in the apatite is a the key factor to determine the chemical reactivity.

Table 3, shows the general composition of some classic rocks as it is compared with some Chilean rocks.

The same samples, submited under analysis with the support of infrared spectrometry, help us to compare its characteristics through the infrared spectrums with some traditional classic rocks such as those of Florida, Bayovar and North Caroline (Figure 2).

This information, allowed to know the index $\mathrm{CO}_{2}$ (Mc Clellan and Gremillion, 1980) and thus, the degree of substitution of $\mathrm{PO}_{4}$ by $\mathrm{CO}_{3}$ in the structure of the apatite, like appropriate indexes of the characterization reactivity of rocks. This way, it has been observed that the rock of Bahia Inglesa and North Caroline, display similar indexes, as well as the one of Mejillones when it is compared with that of Florida of the U.S.A.

\section{Agronomic information of Chilean rocks}

Some experiments developed with rape seed (Brassica napus) showed that this species was able obtain phosphorus from phosphoric rocks very efficiently. This behaviour may be explained through local acidification of rizosphere by organic acids exudates.

This effects was specially remarkable on Andisoils of the IX Region. However, in the same soils, experiments including grain legumes, such as pea and lentils, which are considered acidifying crops, showed that these crops were not able to obtain enough phosphorus from phosphate rocks for their successful plant nutrition.

The conclusions obtained after developing apropiate field experiments, in Andisoils of Chile is that national phosphoric rocks exhibit a fertilizing potential. Most recommendable rock for using as direct phosphorus fertilizer is Bahia Inglesa by its average phosphorus content, and suitable reactivity. The rock of Mejillones, although is of excellent quality, it has a low phosphorus content $(2.2 \%)$ but when concentrating it to $22 \%$ of $\mathrm{P}_{2} \mathrm{O}_{5}$ in experiments including rape seeds, it was as efficient as the SFT (Besoaín et.al., 1999).

The most advisable crops, in which a good efficiency of phosphorus released by national phosphoric rocks was observed, were those of long vegetative period, like prairies, and species with high extractive phosphorus capacity like lupine, rape seed or still in rice, in state of semi permanent flood production where long-term dissolution may occur (Ortega y Rojas, 1999).

\section{Annual Production of Phosphate rocks}

The annual production of phosphate rocks is limited, including the activity of extraction of the Rock of Bahia Inglesa and in smaller degree the one located at Mejillones, which is the low law. This restrict the supply in the country and is fulfilled with the imports of Super Phosphate (SP), Diammonium Phosphate (DAP) and Monoammonium Phosphate (MAP). First these fertilizer materials came mainly from the USA, and Mexico, whereas MAP is come from USA. In Table 4, the yearly production of Chilean most common fertilizers are presented where natural Chilean nitrate is included 
('salitre'), potassium nitrate and potassium nitrate. Most of these fertilizers is exported and its production is obtained mainly from the Chilean pebble in a brick like raw material that extends by the desert between the limit with Peru and the Copiapo river (Figure 1). The trade of natural Chilean nitrate in 2004, was about 59.5 thousands metric tons, and 706.8 thousands metric tons of potassium nitrate in the same year. Respect to the commercialization of phosphoric rocks, these are sold out mainly in internal form in the country as grounded phosphate rocks for direct use, specially in prairies. The direct use in acid prairie soils of the $10^{\text {th }}$ Region in Chile, has been preferred, and also like elaborated granulated product (around 1-2 mm diameter) with the name of "BIFOX" (18\% of $\mathrm{P}_{2} \mathrm{O}_{5}$ ).

According to the available information, of the totality of produced apatite, 10,130 tons are only used for direct use in agriculture, with the inclusion of industrial grinding. However, 8,732 tons correspond to the product derived from the rock of Bahia Inglesa named "BIFOX" that includes certain processing to obtain a granulated fertilizer.

\section{CONCLUSIONS}

Conclusions obtained from Chilean phosphate rocks in its evaluation from numerous field experiments (Montenegro et. al., 1992; Campillo, 1999; Montenegro et al., 1999; Ortega and Rojas,1999) are the following :

In general, the most recommendable rocks for agricultural use in direct application are those of Bahia Inglesa (according to phosphorus content and reactivity). The rock of Mejillones (of low phosphorus content, $2,2 \%$ ), nevertheless is one suitable to be concentrated in order to obtain successful results.

The crops of greater response obtained in the field experiments evaluations, are those of long vegetative period, such as

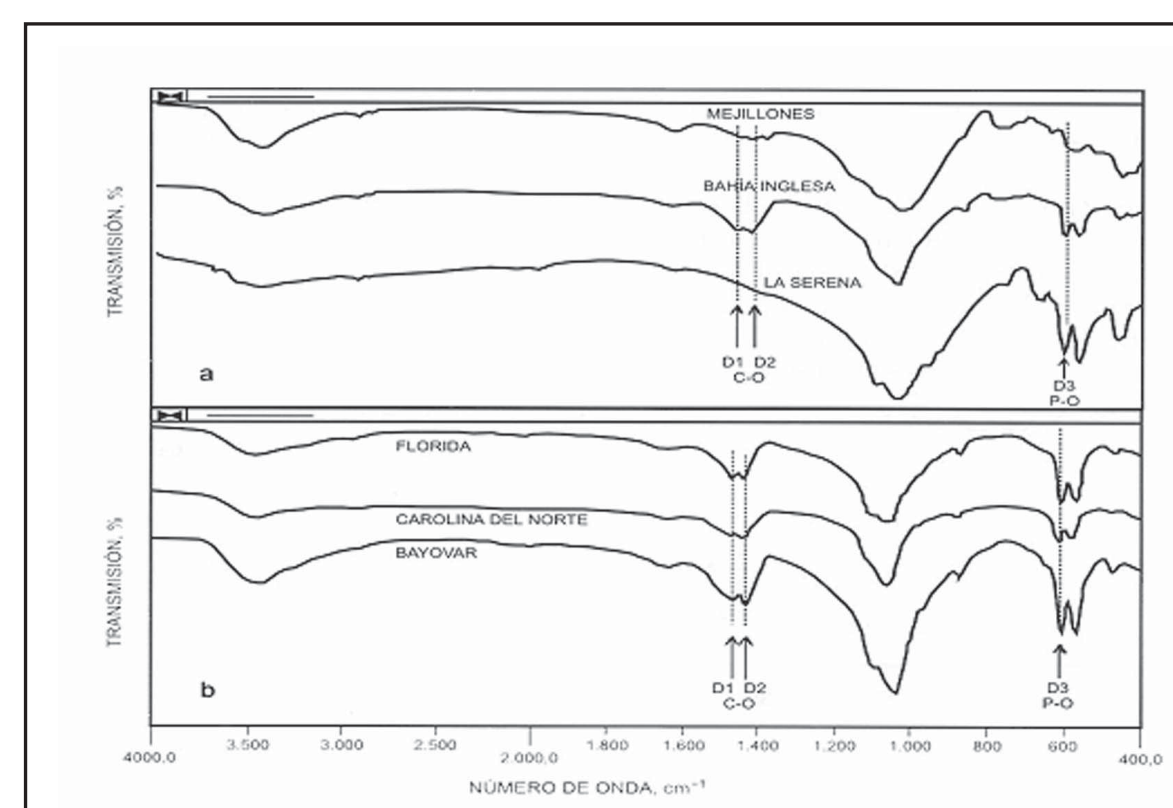

Figure 2: Infrared spectra of foreign and national phosphoric Rocks.

Figura 2: Espectros infrarojos de rocas fósforicas nacionales y extranjeras 
Table 3: Mineral composition of phosphoric rocks.

Cuadro 3: Composición Mineral de las rocas fosfóricas.

Phosphoric rocks

\begin{tabular}{|l|c|c|c|c|c|c|}
\hline \multicolumn{1}{|c|}{ Components } & $\begin{array}{c}\text { La } \\
\text { Serena }\end{array}$ & Mejillones & $\begin{array}{c}\text { Bahia } \\
\text { Inglesa }\end{array}$ & Florida & $\begin{array}{c}\text { North } \\
\text { Carolina }\end{array}$ & Bayovar \\
\hline Carbonates apatite & -- & 3 & 5 & 5 & 5 & 5 \\
Clorhidroxiapatite & 5 & -- & -- & -- & -- & -- \\
Cuarzum & tr & 3 & 2 & 2 & 1 & 1 \\
Plagioclasa & -- & 5 & 2 & 2 & 1 & 1 \\
Biotite & -- & 1 & -- & $\operatorname{tr}$ & -- & -- \\
Anfibol & 2 & 1 & $\operatorname{tr}$ & $\operatorname{tr}$ & -- & -- \\
Clorite & -- & 1 & -- & -- & -- & -- \\
Gipsum & 1 & 1 & -- & -- & -- & -- \\
Ilmenite & -- & 1 & -- & -- & -- & -- \\
Calcite & 1 & 1 & 1 & 1 & 1 & 1 \\
Others & 1 & 1 & 1 & 1 & 1 & 1 \\
\hline
\end{tabular}

Frecuency Coeficients: $5=$ dominant, 4 abundant, $3=$ common, $2=$ present, $1=$ rare.

* Halite, epsomite, caolinite, dolomite. (Besoaín E. et.al, 1999).

prairies and other crops such as lupine, rape seed, and still rice in state of semi permanent flooding.

Since the Chilean phosphate rock production is quite limited. Chile is forced to perform phosphate fertilizer import.

Actually, recommendations for farmers are oriented towards the following practices: a) Prefer phosphate rocks with high reactivity, with dissolutions in neutral citrate ammonium greater than 5,9\%.

b) Prefer to use in soil with $\mathrm{pH}$ lower than 6 . c) Use them in crops of low $P$ requirements in the initial growth cycle.

d) Use rocks with enough phosphate content.

\section{ACKNOWLEDGMENTS}

We are thankful for financial support provided by Texas Gulf Corporation, and Bifox Ltda., and also to Dr. Besoaín E. (died on 2004) for his permanent encouragement and advise. 


\section{REFERENCES}

BESOAÍN E. 1999 a. Recursos fosfóricos de Chile En: Besoaín y Rojas C.F.and Montenegro,A. (eds). Las rocas fosfóricas y sus posibilidades de uso agrícola en Chile (INIA), Chile: 58-62 p.

BESOAÍN E., SEPULVEDA G. $\mathrm{y}$ MOLINA, R. 1999 b. Caracterización mineralógica y química de rocas fosfóricas chilenas. En: Besoaín E., Rojas C. F. y Montenegro, A. (eds). Las rocas fosfóricas y sus posibilidades de uso agrícola en Chile INIA-Chile: $107-120 \mathrm{p}$.

BESOAIN E., SEPULVEDA G. y MOLINA, R. 1999c: Caracterización mineralógica y química de rocas fosfóricas chilenas. En Besoaín E. Rojas, C. F. y Montenegro, A. (eds). Las rocas fosfóricas y sus posibilidades de uso agrícola en Chile INIAChile: 107-120 p.

BESOAIN E., MONTENEGRO B. A. y ROJAS, C.F. 1999d. Discusión y Conclusiones. En: Besoaín E. Rojas, C. F. y Montenegro, A. (eds). Las rocas fosfóricas y sus posibilidades de uso agrícola en Chile INIA-Chile : 311-328p.

CAMPILLO R. 1999. Evaluación agronómica de rocas fosfóricas sobre suelos de praderas naturalizadas de la IX Región. En: Besoaín E., Rojas, C. F. y Montenegro, A. (eds).. Rojas, C. F. y Montenegro, A. (eds). Las rocas fosfóricas y sus posibilidades de uso agrícola en Chile INIA-Chile p.:283-298.

CHIEN S. H. 1977b. Themodynamic considerations on the solubility of phosphate rock. Soil Sci.123: 117-121 p.

FAO 2004. Use of phosphate Rocks for Sustainable Agriculture. FAO Fertilizer and Plant Nutrition. Bulletin 13 Joint the FAO/IAEA Division of Nuclear Techniques In
Food and Agriculture and Land and Water Development Division (AGL). FAO, Rome.

GUARACHI L. P. 1989. Diagnóstico de la minería no metálica en Chile. INTECCORFO $2^{\circ}$ Ed. 503p.

LEHR, J.R. 1967. Variation in composition of phosphate ores and related reactivity. Proceeding of the 7 th meeting: Fertilizer Industry Round Table: Washington, D.C. p: 61-67.

LEON A. 1999. Empleo de las rocas en Iberoamérica. En: Besoaín Besoaín E., Rojas, C. F. y Montenegro, A. (eds).. Rojas, C. F. y Montenegro, A. (eds). Las rocas fosfóricas y sus posibilidades de uso agrícola en Chile INIA-Chile p.:63-84.

MC CLELLAN and L.R. GREMILLION. 1980. Evaluation of phosphatic row materials. In: F.E. Khasawneh et.al. (ed.) The role of phosphorus in agriculture. ASA, CSSA, SSSA Madison, Wisc., The USA p: 43-80.

MONTENEGRO B.A., BESOAIN E., TORO QC. y CONTRERAS, E. 1992. Evaluación agronómica de rocas fosfóricas en el cultivo de trigo en suelos volcánicos de la IX Región. En: Rojas C.F. (ed) Seminario Nacional sobre usos de rocas fosfóricas en Agricultura INIA-Chile, Temuco. Serie Carillanca $\mathrm{N}^{\circ} 29,283-317 \mathrm{p}$.

MONTENEGRO B.A., BESOAIN E. y TORO, C. 1999.Aplicación directa de rocas fosfóricas y mezclas de rocas con fertilizantes solubles en el cultivo del raps, en Andisoles de la IX Región. En: Las rocas fosfóricas y sus posibilidades de uso agrícola en Chile INIA-Chile p. :255-270.

ORTEGA R. y ROJAS C.F. 1999. Evaluación agronómica del efecto de fuentes fosforadas en arroz inundado, en suelos de la VIII Región. En: Las rocas fosfóricas y sus posibilidades de uso agrícola. INIA-Chile p: 247-254. 
OSSES L. 1986. Exploración geológica de rocas fosfóricas sedimentarias (fosforitas) en Chile. CORFO, Santiago, Chile. Informe Reservado. 18p.

ROJAS C.F. y BESOAIN E. 1991. Estudio tgronómico de rocas fosfóricas chienas. Revista Fac. Agron. (MaracayVenezuela) $\mathrm{N}^{\mathrm{o}}$ 17: 111-123.
VALDEBENITO E. M., Y GUTIÉRREZ, A. 1979. Exploración de fosforitas en la península de Mejillones. II Congreso Geológico chileno. Arica, Chile, 6 al 11 de Agosto 1979 p: C307C328. 